\title{
HUBUNGAN ANTARA BODY IMAGE DENGAN PERILAKU DIET PADA SISWI DI SMA KRISTEN 1 SALATIGA
}

\author{
Chatarina Anita Lyana Sari', Christiana Hari Soejiningsih ${ }^{2}$ \\ Email: chatarina008@gmail.com ${ }^{1}$ \\ Fakultas Psikologi, Universitas Kristen Satya Wacana Salatiga ${ }^{1,2}$
}

\begin{abstract}
Abstrak
Body image adalah proses memahami gambaran mental terhadap bentuk dan ukuran tubuh seseorang individu. Kepedulian terhadap penampilan dan body image yang ideal dapat mengarah kepada upaya obsesif seperti mengontrol berat badan terlebih pada siswi SMA yang sering merasa memiliki body image negative, sehingga banyak dari mereka yang melakukan diet untuk mendapatkan body image yang mereka inginkan. Pengambilan sampel dengan menggunakan non-random sampel yaitu peneliti memilih Snowbal sampling. Penelitian ini merupakan penelitian yang bersifat korelasional yang bertuuan untuk mengetahui hubungan antara body image dengan perilaku diet pada siswi SMA Kristen 1 Salatiga. Populasi dan sampel penelitian ini adalah 50 orang siswi di SMA Kristen 1 Salatiga. Penelitian ini menggunakan dua buah skala sebaga alat ukur, yaitu Skala Bodi Image dan Skala Perilaku Diet. Skala Body Image terdiri dari 25 item dan dengan koefisien 0,896 sedangkan skala perilaku diet terdiri dari 19 item dengan koefien 0,198.

Analisa penelitian menggunakan korelasi Pearson Product Moment. Berdasarkan hasil analisa bahwa terdapat hubungan negative antara body image dengan perilaku diet dengan nilai $\mathrm{r}=-0,484$ dengan sig. $=$ $0,000(\mathrm{p}<0,05)$. Yang artinya semakin positing body image maka intensitas perilaku diet yang dilakukan akan semakin rendah begitu pula dengan sebaliknya, semakin negative body image maka intensitas perilaku diet yang dilakukan akan semakin tinggi.
\end{abstract}

\section{Kata kunci : Body Image, Perilaku Diet}

\section{PENDAHULUAN}

Body image bagi remaja merupakan suatu hal yang penting, karena pada masa remaja seseorang banyak mengalami perubahan baik secara fisik maupun psikis. Perubahan ini menimbulkan respon tersendiri bagi remaja seperti tingkah laku yang sangat memperhatikan perubahan bentuk tubuhnya. Hal ini sesuai dengan pendapat Conger dan Peterson (dalam Sarafino, 1998) yang mengatakan bahwa pada masa remaja, para remaja biasanya mulai bersibuk diri dengan penampilan fisik mereka dan ingin mengubah penampilan mereka. Keinginan ini disebabkan karena remaja seringkali merasa tidak puas terhadap penampilan diri mereka. Bagaimana perasaan seseorang mengenai penampilan fisik inilah yang disebut dengan body image (Valencia, 2008). Body image dapat juga didefinisikan sebagai derajat kepuasan individu terhadap dirinya secara fisik yang mencangkup ukuran,bentuk,dan penampilan umum (Cash dan Deagle dalam Valencia, 2008).

Pada usia remaja banyak dari mereka yang berusaha mengubah penampilan mereka sehingga terlihat lebih menarik. Kepedulian terhadap penampilan dan gambaran tubuh yang ideal dapat mengarah kepada upaya obsesif seperti mengontrol berat badan (Davison \& Birch dalam Papalia, 2008). Pada umumnya remaja melakukan diet, 
berolahraga, melakukan perawatan tubuh, mengkonsumsi obat pelangsing dan lainlain untuk mendapatkan berat badan yang ideal (Dacey Kenny, 2001). Konsep tubuh yang ideal pada perempuan adalah tubuh yang langsing (Sanggarwaty, 2003), sedangkan pada laki-laki adalah tubuh yang berisi, berotot, berdada bidang, serta biseps yang menonjol (McCabe, 2004).

Diet didefinisikan sebagai kegiatan membatasi dan mengontrol makanan yang akan dimakan dengan tujuan untuk mengurangi dan mempertahankan berat badan (Hawks, 2008). Kim dan Lennon (2006) mengatakan bahwa diet mencangkup pola-pola perilaku yang bervariasi dari pemilihan makanan yang baik untuk kesehatan sampai pembatasan sangat ketat akan konsumsi kalori. Berdasarkan survey terungkap bahwa $60 \%$ wanita memiliki pola makan yang tidak teratur dengan menghindari sarapan pagi. Menurut Ilyas (Kompas, 2009) diet yang sebenarnya adalah dengan cara mengkombinasikan makanan dan minuman yang kita konsumsi setiap hari, yaitu kombinsi antara 60-70\% karbohidrat, $10-15 \%$ protein dan $20-25 \%$ lemak. Perilaku tidak sehat yang dapat diasosiasikan dengan diet misalnya puasa, tidak makan dengan sengaja, penggunaan pil-pil diet, penahan nafsu makan atau laxative, muntah dengan sengaja atau bulimia, dan binge eating (French, Perry, Leon \& Fulkerson, 1995).

Fenomena yang sering terjadi dikalangan remaja untuk merubah penampilan mereka adalah melalui cara diet. Memiliki tubuh yang ideal merupakan idaman hampir setiap remaja, apalagi pada masa pubertas remaja sangat memperhatikan bentuk mereka tidak terkecuali remaja perempuan maupun remaja laki-laki. Bagi remaja perempuan memiliki tubuh yang ideal dianggap sangatlah penting karena dengan itu mereka dianggap cantik. Sedangkan bagi remaja laki-laki mereka biasanya lebih tertuju dengan membentuk badan mereka seperti membentuk otot. Hal ini juga terjadi di sekolah SMA Kristen 1 salatiga yang dimana remaja disana sangat memperhatikan tubuh mereka. Para remaja bahkan bersaing untuk mendapatkan tubuh yang semenarik mungkin. Remaja perempuan SMA Kristen 1 Salatiga mempunyai rasa kepedulian tersendiri dengan bentuk tubuh nya. Bahkan tak jarang dari remaja perempuan yang memiliki berat badan yang berlebih menjadi bahan olok-olokan teman-temannya sehingga timbul rasa minder dalam dirinya dan dari mereka dikucilkan dengan temen-temannya, tetapi dari olokan tersebut timbul 
keinginan melakukan diet untuk mendapatkan tubuh yang ideal dan tidak menjadi bahan olok-olokan temannya lagi. Tetapi banyak diantara mereka yang berniat melakukan diet tapi dengan menggunakan cara diet yang salah hanya demi mendapatkan tubuh yang ideal dengan cara instan. Bukannya membuat tubuh sehat tetapi menjadi timbulnya penyakit, apalagi masa remaja masih dalam masa pertumbuhan sehingga tidak bisa melakukan diet dengan sembarangan. Namun ini berbeda dengan remaja laki-laki di SMA Kristen 1 Salatiga yang tidak terlalu memperdulikan bentuk tubuhnya dan mereka jarang sekali melakukan diet. Mereka lebih fokus dengan hobby mereka, yang dominan pada bidang olahraga seperti basket, voli. Tak jarang dari remaja laki-laki belum terlalu memikirkan bentuk badan seperti membentuk otot. Remaja laki-laki lebih cenderung percaya diri dengan bentuk tubuhnya dan berpikir santai dan sangat jarang sekali mereka melakukan diet. Oleh karena itu partisipan penelitian ini adalah siswa perempuan yang khususnya melakukan diet.

Diet merupakan sesuatu yang sangat menarik pada jaman sekarang. Namun pola makan yang tidak terbatas banyak pilihan serta citra rasa tinggi ada kalanya menyebabkan obesitas dan membuat tubuh menjadi terlihat tidak menarik dan menjadi kurang sehat. Ogden (2002) menyatakan sebaliknya yaitu bahwa orang yang mempunyai keinginan untuk mengubah bentuk tubuhnya tidak selalu melakukan diet. Beberapa orang lebih memilih untuk mengenakan baju-baju yang merwarna gelap karena dengan menggunakan baju berwarna gelap membuat mereka terlihat kurus. Hal ini menunjukkan bahwa ternyata seseorang yang memiliki rasa tidak puas terhadap bentuk tubuhnya belum tentu selalu melakukan diet melainkan mereka juga dapat memilih cara lain untuk memperbaiki bentuk tubuhnya dan penampilannya. Keadaan seperti itu yang seringkali membuat seseorang tidak dapat menerima kondisi fisiknya dengan apa adanya sehingga body image menjadi negatif. Hal tersebut yang mendorong seseorang untuk mengambil keputusan untuk melakukan diet yang pada dasarnya dilakukan untuk mengurangi tekanan karena penilaian yang negatif terhadap body image yang tidak sesuai dengan gambaran idealnya.

Hal ini sejalan dengan penelitian sebelumnya yang dilakukan oleh Winzeler (2005) yang menyatakan bahwa remaja laki-laki lebih bangga dengan bentuk tubuhnya dan lebih puas dengan 
berat badannya sebesar $73 \%$ dari pada remaja perempuan yang hanya sebesar 47\%. Berdasarkan pemaparan diatas menunjukkan adanya perbedaan tingkat ketidakpuasaan yang pada akhirnya membuat remaja menjadi tidak percaya diri dan menganggap penampilannya sebagai sesuatu yang menakutkan. Hasil penelitian yang dilakukan oleh Pope, Philip, dan Olivardia (2000) menunjukkan bahwa perempuan lebih memperhatikan penampilan fisiknya dibandingkan laki-laki. Penjelasan ini bukan berarti penampilan fisik yang menarik hanya pada perempuan saja tetapi laki-laki pun terkadang memperhatikan penampilan mereka. Ketidakpuasan terhadap gambaran tubuh pada remaja perempuan umumnya mencerminkan keinginan untuk menjadi lebih langsing (Davison, Markey \& Birch dalam markey, 2005). Berdasarkan hasil survei yang dilakukan majalah perempuan Glamour, diperoleh hasil bahwa dari 4000 remaja perempuan, hanya $19 \%$ saja yang merasa puas akan tubuhnya, dan sisanya $81 \%$ merasa tidak puas dan cenderung melakukan diet. Sebuah penelitian (Cash dan Pruzinsky, 2002: 74 )menjelaskan bahwa sekitar 40$70 \%$ gadis remaja tidak puas dengan dua atau lebih aspek dari tubuh mereka. ketidakpuasan biasanya berfokus pada jaringan adipose substansial dalam tubuh bagian tengah atau bawah, seperti pinggul, perut dan paha. Di berbagai Negara maju, antara 50- $80 \%$ gadis remaja ingin menjadi langsing dan melakukan diet bervariasi dari $20 \%$ hingga $60 \%$. Hasil penelitian yang dilakukan oleh Wal (2011) di Saint Louis University, USA kepada 2.409 remaja perempuan didapatkan data bahwa pola perilaku mengontrol berat badan secara tidak sehat banyak dilakukan yaitu $46,6 \%$ remaja perempuan sengaja melewatkan makan (sarapan, makan siang, ataupun makan malam), $16 \%$ remaja perempuan berpuasa untuk menguruskan badan, $12,9 \%$ remaja perempuan membatasi atau menolak satu jenis makanan atau lebih untuk diet yang ketat, $8,9 \%$ remaja perempuan menggunakan pil-pil diet atau pil-pil pengurus badan, $6,6 \%$ remaja perempuan merokok untuk menurunkan berat badan, dan 6,6\% remaja perempuan memuntahkan makanan dengan paksa.

Ketidakpuasan terhadap gambaran tubuh pada remaja perempuan umumnya mencerminkan keinginan untuk menjadi lebih langsing (Davison, Markey \& Birch dalam markey, 2005). Dan hasil penelitian dari Mariyati, M, Makdalena (dalam jural yang berjudul Hubungan Body Image dengan Perilaku Diet Pada Remaja Putri Kelas X Di SMA N 1 
Jepara) Perilaku diet tinggi sebanyak 46 siswa $(66,7 \%)$, perilaku diet sedang sebanyak 19 siswa $(27,5 \%)$, dan perilaku diet rendah sebanyak 4 siswa $(5,8 \%)$. Body image pada remaja di kelas XI IPA 3 dan 4 SMA N 1 Polanharjo termasuk dalam kategori positif yaitu $71,67 \%$ dan perilaku diet dalam kategori baik yaitu 98,33\% dan ada hubungan atara body image dengan perilaku diet, semakin positif body image maka semakin baik perilaku diet pada remaja dan begitu pula sebaliknya.

\section{TINJAUAN PUSTAKA}

Body Image, dapat juga didefiniskan sebagai derajat kepuasa individu terhadap dirinya secara fisik yang mencangkup ukuran, bentuk, dan penampilan umum (Cash, 2002). Ada tujuh aspek dalam body image yaitu Physical attractiveness, Body image satisfaction, Body image importance, Body concealment, Body improvement, Social physique anxiety, Appearance comparison.

\section{Perilaku Diet}

Polivy, Herman dan Warsh (2010) mengemukakan bahwa perilaku diet merupakan usaha membatasi makanan yang sengaja dilakukan oleh individu dan berlangsung secara terus menerus dengan tujuan menurunkan berat badan dan menjaga keseimbangan berat badan. dan terdapat tiga aspek, yaitu : aspek eksternal, aspek emosional, dan aspek restraint.

\section{METODE PENELITIAN}

Subjek penelitian ini adalah siswi SMA Kristen 1 Salatiga dengan rentang usia antara 15-18 tahun dan siswi yang melakukan diet.

\section{Metode Pengumpulan Data}

Penelitian ini menggunakan skala sebagai metode pengumpulan data. Skala merupakan daftar pernyataan yang harus diisi oleh subjek penelitian. Adapaun skala yang digunakan dalam penelitian ini adalah skala body image dan skala perilaku diet.

\section{Metode Analisis Data}

Data dari penelitian ini berupa data kuantitatif. Sesuai dengan tuuan dari penelitian ini yaitu ingin mengetahui hubungan antara body image dengan perilaku, maka digunakan Teknik statistic korelasi yaitu korelasional Product Moment Pearson (Azwar, 2007). Sebelum dilakukan uji Product Moment Pearson, terlebih dahulu dilakukan uji normalitas dan linearitas sebagai persyaratan uji hipotesis.

\section{A. Hasil Penelitian}

\section{Deskriptif Data Penelitian}

Kriteria Skor Body Image. Data menunjukkan tingkat body image dari 50 subjek yang berbeda-beda, mulai dari 
tingkat sangat rendah hinga sangat tinggi.

Pada kategori sangat rendah didapati persentasi sebesar 1,6\%, kategori rendah $11,3 \%$, kategori tinggi $22,6 \%$ dan kategori sangat tinggi $64,5 \%$. Mean/ Rata-rata yang diperoleh adalah 94,60.

Kriteria Skor Perilaku Diet. Data di atas menunjukkan tingkat perilaku diet dari 50 subjek yang berbeda-beda mulai dari tingkat rendah, sedang hingga tinggi. Pada kategori rendah didapati persentase $8,06 \%$, kategori sedang $30,6 \%$, dan kategori tinggi 61,29\%. Mean atau ratarata yang diperoleh adalah 89,19.

\section{Hasil Uji Asumsi}

\section{Uji Normalitas}

Tabel 1

Hasil Uji Normalitas

\begin{tabular}{|c|c|c|c|}
\hline & & body_imag & $\begin{array}{l}\text { Perilak } \\
\text { u_diet }\end{array}$ \\
\hline $\mathrm{N}$ & & 62 & 62 \\
\hline \multirow[t]{2}{*}{ Normal Parameters ${ }^{a}$} & Mean & 94.60 & 89.19 \\
\hline & $\begin{array}{l}\text { Std. } \\
\text { Deviation }\end{array}$ & 13.572 & 12.768 \\
\hline Extreme & Absolute & .093 & .117 \\
\hline \multirow[t]{2}{*}{ Differences } & Positive & .093 & .078 \\
\hline & Negative & -.064 & -.117 \\
\hline Kolmogorov-Smirnov Z & & .730 & .925 \\
\hline Asymp. Sig. (2-tailed) & & .662 & .359 \\
\hline
\end{tabular}

Hasil perhitungan uji kolmogorov-smirnov $\mathrm{Z}$ diperoleh besar nilai K-S-Z sebesar 0,730 dengan nilai sign $=0,662 \quad($ nilai $\mathrm{p}>0.05)$ dengan perilaku diet juga sebesar nilai K-S-Z sebesar 0,925 dengan nilai sign $=0,359$ (nilai $\mathrm{p}>0.05$ ). dari data tersebut artinya kedua variable tersebut berdistribusi normal.

\section{Hasil Uji Linearitas}

Uji Linearitas, Pengujian linearitas diperlukan untuk mengetahui apakah variable yang sudah ditetapkan, memiliki hubungan yang linear atau tidak secara signifikan. Kedua variabel dapat dikatakan linier bila memiliki nilali signifikansi deviation from linearity ( $\mathrm{p}>$ 0,05). Berdasarkan uji linearitas yang telah dilakukan menunjukkan adanya hubungan yang linear antara body image dengan perilaku diet, karena dari hasil uji linearitas diperoleh $\mathrm{F}$ beda $=2,255$ dengan signifikansi sebesar 0,150 (p> 0,05). Oleh karena itu dapat dikatakan bahwa hubungan antara body image dengan perilaku diet menunjukkan garis yang sejajar atau linear.

\section{Hasil Uji Korelasi}

Tabel 2

Hasil Uji Korelasi

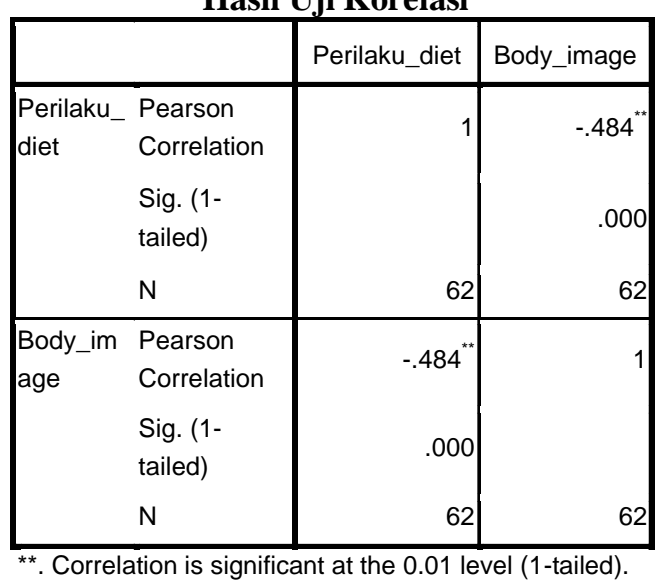




\section{PEMBAHASAN}

Berdasarkan hasil perhitungan korelasi product moment Pearson antara variable Body Imgae dengan perilaku diet menunjukkan $\mathrm{r}=0,484$ dengan signifikansi sebesar 0,000 ( $>0,05)$. Hasil tersebut menandakan $\mathrm{H}_{0}$ ditolak dan $\mathrm{H}_{1}$ diterima dan menunjukkan bahwa terdapat hubungan negatif dan signifikan antara Body Image dengan perilaku diet.

Hasil penelitian ini mengungkapkan bahwa variable X (Body Image) dan variable $\mathrm{Y}$ (perilaku diet) memiliki hubungan negative dan signifikan. Hasil ini sesuai dengan penelitian Husna (2013) dalam penelitiannya bahwa body image memiliki hubungan negative dengan perilaku diet. Body image memiliki peranan terhadap perilaku diet seseorang. Jadi jika seseorang memiliki body image yang negative maka perilaku diet yang dilakukan semakin tinggi, begitupun sebaliknya semakipositif body image maka perilaku diet yang dilakukan akan semakin rendah.

Bayyari (2010) juga mengatakan bahwa body image yang buruk menjadi faktor yang tidak dapat dihindari dan mengakibatkan emosi yang negatif seperti perasaan kecewa, cemas, dan depresi sehingga sangat dimungkinkan seseorang memunculkan perilaku yang menyimpang. Di dalam hubungannya terhadap strategi penurunan berat badan, body image yang buruk akan menimbulkan perilaku diet yang tidak sehat atau negatif.

Husna (2013) juga mengungkapkan bahwa salah satu faktor yang mempengaruhi perilaku diet adalah faktor kepribadian seseorang yang berkaitan dengan kepercayaan diri terhadap bentuk tubuhnya. Ketidaksesuaian antara gambaran ideal dengan persepsi terhadap diri dapat menyebabkan body image menjadi negatif. Jika seseorang merasa tidak percaya diri dengan kondisi tubuhnya, maka ia akan melakukan diet untuk mendapatkan tubuh yang ideal. Oleh karena itu sangatlah penting bagi remaja untuk memiliki body image yang positif sehingga dapat menerima keadaan dirinya dan tetap tampil percaya diri

\section{KESIMPULAN DAN SARAN}

Berdasarkan pada hasil penelitian yang telah dilakukan dapat disimpulkan sebagai berikut :

1. Dari hasil uji korelasi, menunjukkan bahwa ada hubungan negative antara body image dan perilaku diet pada siswi.

2. Semakin positif body image seseorang maka frekuensi untuk melakukan diet semakin kecil. Sebaliknya, jika semakin negative 
body image seseorang maka

frekuensi untuk melakukan diet semakin besar.

Berdasarkan hasil penelitian yang didapat, maka saran yang diberikan peneliti yaitu :

1. Bagi siswa

- Sangat penting bagi siswi untuk memiliki body image yang positif supaya tidak melakukan Tindakan negative, seperti melakukan diet yang tidak sehat untuk memperbaiki penampilan.

- Disarankan untuk siswi agar tetap menjaga pola hidup sehat

\section{DAFTAR PUSTAKA}

Azwar, S (2007). Penyusunan skala psikologi (edisi pertama), Yogjakarta: Pustaka Pelaar Offset.

Bayyari, W. (2010). Predictors of dieting among female college students at Palestinian Universities: an exploratory study. Poquest Dissertation and Theses: The

Cash T.F. \& Pruzinsky. 2002. Body Image: A Handbook of Theory, Research and Clinical Practice. Guilford Press

Cash T.F. \& Pruzinsky. (2002. Body Image attitude: Evaluation, investment, and affect:Perceptual motor skills. Journal of Psycology, (78), 1116-1179. untuk menjaga berat badan tetap ideal.

2. Bagi peneliti selanjutnya

- Bagi peneliti selanjutnya diharapkan dapat mengembangkan penelitian ini dengan menambahkan variable-variabel lain yang berkaitan misalnya media sosial dan tekanan teman sebaya.

- Peneliti selanjutnya perlu memperhatikan kriteria subjek diantaranya, remaja yang melakukan diet.

Dacey, J. \& Kenny, M. (2001). Adolescent development (2th ed). USA:Brown \& Benchmark Publishers.

French, S.A.,Perry, C.L.1995. Dieting Behavioral and weight change history in female adoloscent. Journal of health psychology, 14 (548-555)

Hawks, Steven R. (2008). Classroom approach for managing dietary restraint, negative eatingstyle, and body image concerns among college women, Journal of American collegehealth, Vol. 56, No. 4.

Husna, N. L. (2013). Hubungan Antara Body Image Dengan Perilaku Diet. Skripsi Fakultas Psikologi UNES, Semarang. 
Kim, M., \& Lennon, S. J.2006. Analysis of diets advertisements : A cross national comparison of Korean and U.S. womes's magazines.Clothing and textiles researchjournal, 24, 345.

Kompas (2009). Punya tubuh indah, bukan berarti sehat lho. Jakarta: Jakob Oetama. Tanggal terbit: 10 Juli 2009.

Makdalena, M. Mariyati. 2014. Hubungan Body Image Dengan Perilaku Diet Pada Remaja Putri Kelas X Di SMA N 1 Jepara. Skripsi Fakultas Ilmu Keperawatan, STIKES Widya Husada Semarang

Ogden, J. (2002). Psychology of eating: From healthy to disordered behavior. USA: The Blackwell Publishing. [on-line]. Available FTP: http://books.google.com. Tanggal Akses: 19 April 2017

Papalia, D. E. (2008). Human development (Psikologi perkembangan edisi kesembilan). Jakarta: Kencana.
Polivy, J., Herman, C. P., \& Warsh, S. (1978). Internal and External Components of Emo- tionality in Restrained and Unrestrained Eaters. Journal of Abnormal Psychology, 87(5), 497-504.

Pope, H.G., Phillips, K.A., \& Olivardia, R. (2000). The Adonis complex: The secret crisis ofmale budy obsession. Sydney; The Free Press

Sarafino, Edward. P. (1998). Health psychology: Biopsychososial mechanism (edisikelima).USA: John Wiley \& Sons, Inc

Valencia, Carlo (2008). Body image and self esteem/ [on-line]. AvailableFTP:http://www.selfeste emawareness.com/bodyimage.htm. Tanggal Akses: 19 Februari2009.

Winzeler. A. (2005). A healthy body image. UNH Department of Family Studies. [online]. Available FTP: www.adolescene. unh.edu/healthybodyfinal.pdf. 